\title{
Liquid Supplements for Cattle on Southern
}

Forest Range

\section{HAROLD E. GRELEN AND HENRY A. PEARSON}

Highlight: A molasses-urea mixture fed free-choice yearlong as a supplement to cows on pine-bluestem range produced a higher calf crop and heavier calves than cottonseed cake fed only during winter. Because the liquid supplement required no feeding labor, it was $\$ 14.63$ per cow and $\$ 0.81$ per acre more profitable than the cottonseed cake.

Native forages on southern forest range are deficient in some nutrients throughout the year but are especially poor during winter (Campbell et al. 1954). Supplemental feeding can substantially increase cattle production (Duvall and Whitaker 1963; Duvall and Hansard 1967), but the usual supplements-cottonseed cake and hay-increase labor requirements considerably. Liquid supplements containing molasses and urea can be fed free-choice and may be more economical and equally beneficial.

A study was initiated in November 1969 to determine if liquid supplements fed free-choice would adequately support a yearlong cow-calf operation on southern pine ranges. Preliminary results reported by Pearson (1974) indicated that liquid supplement is not satisfactory when fed in winter only. The data reported here were collected from November 1969 through September 1975, and indicate that liquid supplements have important potential as a yearlong supplement on southern forest range.

\section{Methods}

The study was conducted on the Palustris Experimental Forest in œntral Louisiana on an area where moderate yearlong grazing has been practiced since 1951. Cattle stocking rates are 1.5 acres per animal unit month, and utilization averages about $42 \%$ of the current year's herbage growth.

Soils vary from poorly drained flatwoods to well-drained sandy loams with slopes up to 10\%. Longleaf pine (Pinus palustris Mill.) was clearcut in 1965, and only a scattering of small pines and some scrub oaks (Quercus spp.) remain. The herbaceous vegetation is mainly slender bluestem (Andropogon tener (Nees) Kunth), pinehill bluestem (A. scoparius var. divergens Anderss. ex Hack.), other bluestems, and panicums (Panicum spp.). The primary shrub is southern waxmyrtle (Myrica cerifera L.). Annual herbage production averages about 2,000 pounds per acre.

To improve forage availability and to stimulate new growth, the range is prescribe-burned on a 3-year rotation (Campbell et al. 1954; Duvall and Whitaker 1964). Utilization is heaviest immediately after burning but declines during the second and third years, allowing time for the plants to regain vigor.

Beginning in 1969, two supplementation treatments were compared. The control treatment (CSC) provided 418 pounds of cotton-

Authors are principal range scientist, Southern Forest Experiment Station, Forest Service, U.S. Department of Agriculture, Alexandria, Louisiana; and principal range and wildlife scientist, Forest Service, U.S. Dep. Agr., Washington, D.C.

Manuscript received June 7, 1976. seed cake per cow year on a graduated schedule. Feeding began in November with 1 pound per cow per day and was increased to 3 pounds per day from January 1 to March 10. The daily amount was gradually decreased to 1 pound during April and was kept at that level until feeding ended May 31 . Approximately 260 pounds of grass-legume hay was supplied during the latter part of winter and on cold, rainy days. Whenever cottonseed cake or hay was fed, it was distributed three times a week (Pearson and Whitaker 1972).

In the yearlong liquid supplement treatment (LS), self-feeding roller tanks (Fig. 1) dispensed a liquid supplement mixture of urea and molasses containing $32 \%$ crude protein (Table 1). Some additional hay and range cubes ( $20 \%$ protein) were supplied during severe winter weather. Salt and steamed bonemeal were provided free-choice yearlong in both treatments.

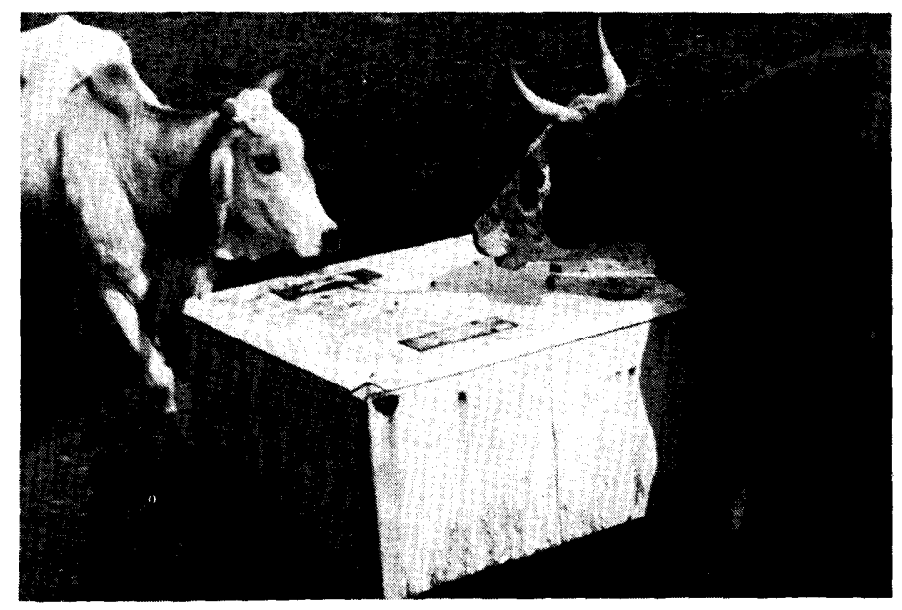

Fig. 1. Liquid supplement was dispensed free-choice yearlong in "lick" tanks.

In November 1969, two herds of 15 Brahman crossbred cows were randomly assigned to the treatments. Each year the cows were bred to good quality Angus bulls for calving in December through March. Calves were weaned and sold in mid-August to allow cows adequate recovery time before winter.

\section{Results and Discussion}

Feed Consumption

Supplemental feed consumption varied with treatment (Table 2). CSC cows ate 418 pounds of cottonseed cake and 260 pounds of grass-legume hay. Cows on the LS treatment averaged 1,200 pounds of liquid feed each year; during the severe winters of 1970,1973, and 1974, they were also given some hay and range cubes.

The LS herd ate no more salt and slightly less steamed bonemeal than the CSC herd. Bonemeal primarily compensates for phosphorus deficiencies, and the phosphorus in the liquid 
Table 1. Label data on contents of liquid supplement.

\begin{tabular}{|c|c|}
\hline Composition & Amount \\
\hline $\begin{array}{l}\text { Crude protein, not less than } \\
\text { (This includes not more than } 30 \% \\
\text { equivalent protein from nonprotein } \\
\text { nitrogen.) }\end{array}$ & $32.00 \%$ \\
\hline Crude fat & None \\
\hline Crude fiber & None \\
\hline Sugar (Invert), not less than & $40.00 \%$ \\
\hline Calcium $(\mathrm{Ca})$, not more than & $1.50 \%$ \\
\hline Calcium $(\mathrm{Ca})$, not less than & $0.50 \%$ \\
\hline Phosphorus (P), not less than & $1.25 \%$ \\
\hline Iodine (I), not less than & $0.0055 \%$ \\
\hline Cobalt (Co), not less than & $0.003 \%$ \\
\hline Copper $(\mathrm{Cu})$, not less than & $0.008 \%$ \\
\hline Iron $(\mathrm{Fe})$, not less than & $0.02 \%$ \\
\hline Zinc $(\mathrm{Zn})$, not less than & $0.0125 \%$ \\
\hline Choline chloride, not less than & $50.00 \mathrm{mg} / \mathrm{lb}$ \\
\hline Vitamin $B_{12}$, not less than & $2.50 \mathrm{mg} / \mathrm{lb}$ \\
\hline Vitamin $\mathbf{A}$, not less than & 30,000 USP Units/lb \\
\hline Vitamin $D_{3}$, not less than & 5,000 USP Units/lb \\
\hline Vitamin $E$, not less than & $10 \mathrm{IU}$ Units/lb \\
\hline
\end{tabular}

supplement perhaps accounts for the decreased bonemeal intake.

Daily intakes of liquid supplement were lowest in winter and highest in summer, and the greatest increase occurred during March and April (Fig. 2). Consumption averaged $1.9 \mathrm{lb} /$ day in winter, $3.5 \mathrm{lb}$ in spring, $4.4 \mathrm{lb}$ in summer, and $3.5 \mathrm{lb}$ in fall. Totusek et al. (1971) reported an average daily consumption of $3.2 \mathrm{lb}$ in winter trials in Oklahoma. Pearson (1974), however, found that cows given liquid supplements only during winter ate less each day than those on a yearlong treatment ate during the winter. Apparently, adjustment periods are necessary whenever the diet is switched to nonprotein nitrogen (Kennedy 1970). Also, some unknown physiological or rumen biological factors may inhibit consumption if liquid supplements are provided only during winter.

Consumption of liquid supplements fluctuated within a given month, especially if a new shipment of feed differed in composition from the previous one. As commercial feeds were used, quality control was impossible, but the variation did not disrupt cattle productivity. Operators who mix their own feed can control intake to some extent by regulating the amount of urea, phosphoric acid, or aluminum sulfate in the feed (Reynolds et al. 1970; Totusek et al. 1971). To prevent overconsumption that may cause urea toxicity, roughage should be

Table 2. Yearly supplement consumption and costs for cows grazing native range.

\begin{tabular}{lrrrrr}
\hline & \multicolumn{4}{c}{ Supplement $^{1}$} \\
\cline { 2 - 3 } \cline { 5 - 5 } Items & \multicolumn{2}{c}{ CSC } & \multicolumn{3}{c}{ LS } \\
\hline Cottonseed cake & lb/cow & $\$$ & lb/cow & $\$$ \\
Liquid supplement & 418 & 23.91 & & 0 & 0 \\
Range cubes & 0 & 0 & 1211 & 52.50 \\
Grass-legume hay & 0 & 0 & 21 & 1.14 \\
Salt & 260 & 4.16 & 19 & .23 \\
Steamed bonemeal & 16 & .30 & 16 & .30 \\
Total & 11 & .98 & & .74 \\
\hline
\end{tabular}

CSC $=$ control treatment with 418 pounds of cottonseed cake per cow on a graduated schedule.

$L S=$ liquid supplement of urea and molasses containing $32 \%$ crude protein.

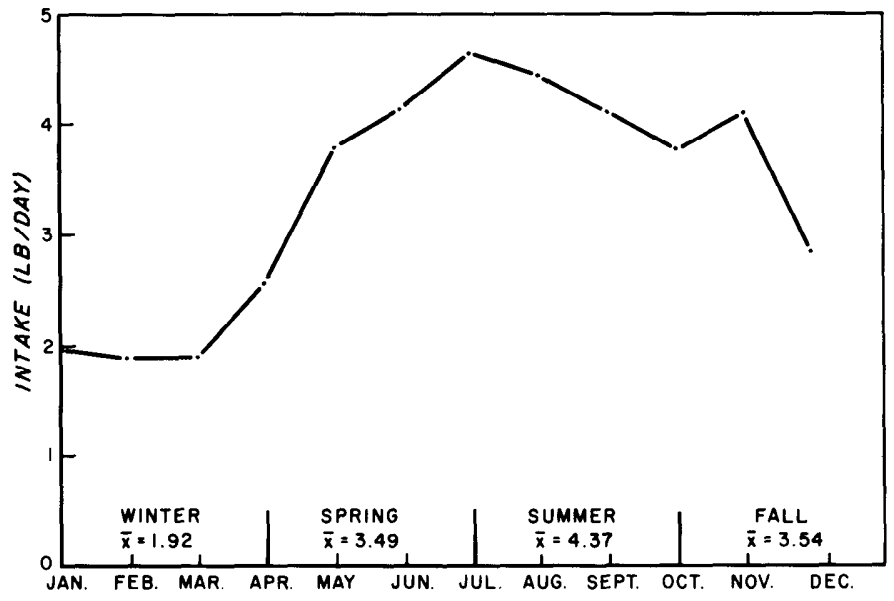

Fig. 2. Liquid supplement intake by cattle.

fed before placing cattle on the molasses-urea mix, and water and roughage should be available continuously (Reynolds et al. 1970).

\section{Cattle Performance}

Generally, cattle performance was better with the liquid supplement (Table 3 ) than with the CSC. LS cows were slightly heavier than the CSC animals. However, the LS herd lost more weight. in winter than the CSC herd; lactating cows with consecutive calves lost $13 \%$ on the CSC treatment, including the calf weight loss, while weight losses on liquid supplements averaged 24\% (Pearson 1974). Totusek et al. (1971) found similar responses with range cows in Oklahoma.

The LS treatment yielded higher calf crops and weaning weights than the CSC treatment; although LS calves were 14 days younger when sold, they averaged 16 pounds heavier than CSC cows. Totusek et al. (1971) found that cows given liquid feed only in winter had lower calf crops than those supplemented with cottonseed meal on an Oklahoma range. A similar reaction to winter-only liquid supplementation also occurred in Louisiana (Pearson 1974).

Table 3. Cattle performance with supplementation programs.

\begin{tabular}{lrr}
\hline & \multicolumn{2}{c}{ Supplement $^{1}$} \\
\cline { 2 - 3 } Items & CSC & LS \\
\hline Cow weight in spring (lb) & 825 & 830 \\
Calf crop (\%) & 82 & 92 \\
Parturition (date) & Jan. 19 & Feb. 2 \\
Sale weight at weaning (lb) & 415 & 431 \\
\hline
\end{tabular}

See footnote on Table 2.

\section{Cost and Returns}

Feed costs were higher, labor and travel costs were lower, and returns were greater with the LS treatment (Table 4). Annual feed costs for the LS treatment were about double the CSC costs. Between 1969 and 1975, liquid supplements averaged $\$ 87$ per ton. Cottonseed cake rose from $\$ 88$ to $\$ 180$ per ton. Range cubes averaged $\$ 106$ per ton; hay, $\$ 32$ per ton; and salt and steamed bonemeal, $\$ 1.85$ and $\$ 9.20$ per hundredweight.

Labor requirements were 7.2 hours per year for the LS herd (\$0.96 per cow) and 90 hours per year for the control herd $(\$ 12.00$ per cow). Labor costs were estimated for management of the 15-cow herds, and labor was computed at $\$ 2.00$ per hour. Hand-feeding cottonseed cake or range cubes and hay required 3 
Table 4. Cost and returns from supplementation programs.

\begin{tabular}{lrr}
\hline & \multicolumn{2}{c}{ Supplement ${ }^{1}$} \\
\cline { 2 - 3 } Items & CSC & LS \\
\hline Gross returns/calf & $\$ 162.06$ & $\$ 174.52$ \\
Gross returns/cow & 132.89 & 160.38 \\
Fced costs/cow & 29.35 & 54.91 \\
Labor and travel costs/cow & 13.80 & 1.10 \\
Net returns/cow & 89.74 & 104.37 \\
Net returns/acre & 4.99 & 5.80 \\
\hline
\end{tabular}

Sec footnote on Table 2 .

Returns based on average price during 1969-75 which varied between $\$ 25$ and $\$ 75 / \mathrm{cwt}$ regardless of supplementation.

hours labor per week. No labor was charged for the general care and maintenance of the herds; consequently, liquid supplement herds had no labor charge except when other supplements were supplied during severe winter weather. The liquid supplement distributor delivered the feed to the tanks.

Travel averaged 6 miles per week at $\$ 0.15$ per mile when cattle were hand-fed. Yearly travel was estimated at 13.5 miles with the LS treatment ( $\$ 0.14$ per cow) and 180 miles for the control ( $\$ 1.80$ per cow).

Equipment costs for cottonseed cake feed troughs, liquid feed roller tanks, barns, corrals, etc., were not included in the cost-return analysis. Liquid feed tanks (metal or fiberglass) range from $\$ 85$ to $\$ 100$ and have an expected longevity of at least 5 years. One tank with two rollers should be sufficient for about 30 cows.

Calves from both treatments sold for about $\$ 40$ per hundredweight. Gross returns per calf were about $\$ 12$ higher for the LS treatment than for the CSC (Table 4). Gross returns per cow were over \$27 more for the LS than for the CSC; combined costs for feed, labor, and mileage were about $\$ 13$ per cow less for the CSC. Consequently, net returns per cow on the LS treatment were $\$ 15$ higher than on the CSC; net returns per acre were about $\$ 0.80$ more. At 1976 prices-cottonseed cake, $\$ 180$ per ton; liquid supplement, $\$ 114$ per ton; cubes, $\$ 138$ per ton; hay, $\$ 40$ per ton; calves, $\$ 27$ per hundredweight-net returns per acre are reduced to $\$ 1.90$ for the CSC and $\$ 2.18$ for the LS treatment.

\section{Literature Cited}

Campbell, R. S., E. A. Epps, Jr., C. C. Moreland, and others. 1954. Nutritive values of native plants of forest range in central Louisiana. Louisiana Agr. Exp. Sta. Bull. 488.18 p.

Duvall, V. L., and S. L. Hansard. 1967. Responses of southern range cattle to protein supplementation. J. Range Manage. 20:153-157.

Duvall, V. L., and L. B. Whitaker. 1963. Supplemental feeding increases beef production on bluestem-longleaf pine ranges. Louisiana Agr. Exp. Sta. Bull. 564. 18 p.

Duvall, V. L., and L. B. Whitaker. 1964. Rotation burning: A forage management system for longleaf pine-bluestem ranges. J. Range Manage. 17: 322-326.

Kennedy, Bill. 1970. Liquid supplements for beef? You can Scratch that! It's no longer a question... The cattle industry is now pouring it on, mixing it in and lapping it up. Louisiana Farmer 7(12):9.

Pearson, H. A. 1974. Liquid supplements for cattle grazing native range. p. 33-40. In: Proc., Louisiana State Univ. 14th Annu. Livestock Prod. Day.

Pearson, H. A., and L. B. Whitaker. 1972. Thrice-weekly supplementation adequate for cows on pine-bluestem range. J. Range Manage. 25:315-316.

Reynolds, W. L., H. C. Gonsoulin, T. M. DeRouen, and others. 1970. Feed molasses and urea mixtures to beef cattle. Louisiana Cattleman 70(11):8-9.

Totusek, R., J. W. Holloway, and W. E. Sharp. 1971. Self-fed liquid and dry supplements for wintering range cows. Oklahoma Agr. Exp. Sta. Misc. Pub. $85: 36-41$.
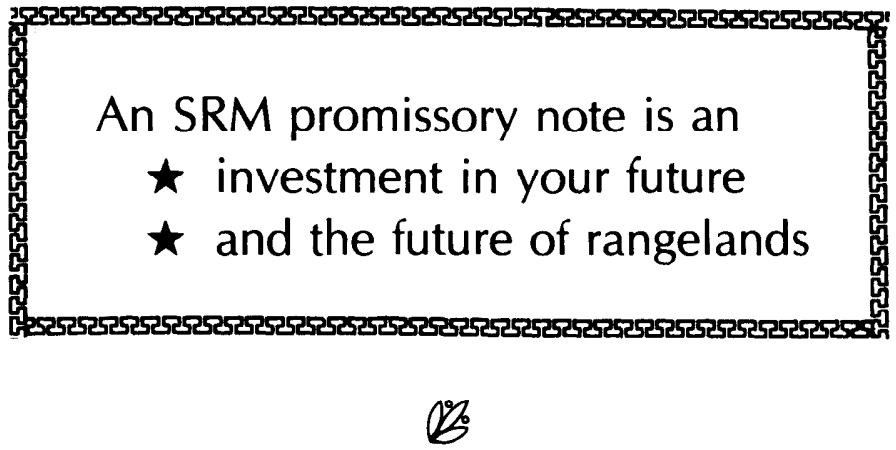

Notes are issued in multiples of $\$ 1,000$

$\star 8 \%$ interest paid semiannually $\star 10$-year maturity

Further details can be obtained by writing or phoning the headquarters of the Society for Range Management, 2760 West Fifth Avenue, Denver, Colorado 80204. (303) 571-0174

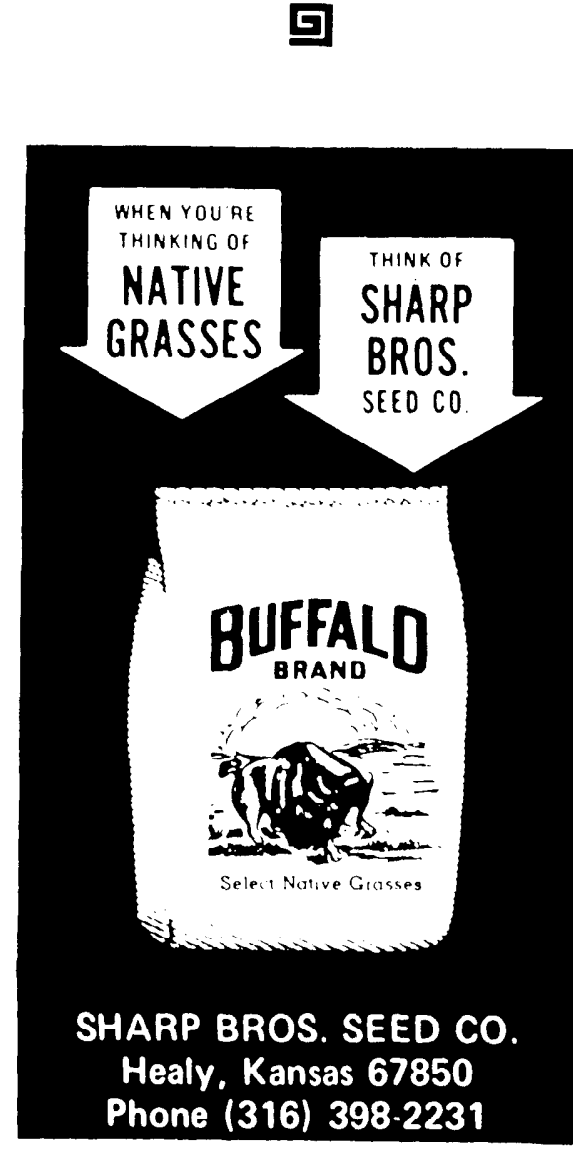

